\title{
(POATE FI) \\ SOCRATE - UN MODEL PENTRU TINERII DE AZI?
}

Laurențiu-Sorin Ormenișan*

\begin{abstract}
Socrates' image, being the ideal image of the philosopher, crosses the centuries. Socrates is the image of the philosopher that is constantly searching. During the dialogues, Socrates claimed his ignorance in teaching the others anything. But he urges his compatriots, not only to think on their own but also to discover the truth by themselves. The effort and the importance of Socrates' attitude are to raise in people the good disquiet to search for virtue and truth. The effort Socrates makes to cast people out of indifference and superficiality must be supported by their own determination and effort to search and find the truth which is inside them.
\end{abstract}

Keywords: self-knowledge, Socrate, philosophy, justice, death, virtue.

\section{Introducere}

A scrie despre un astfel de filosof, dă un sentiment de micime personală, datorită neputinţei de a reda în cuvinte cât mai potrivite, modul de viaţă, atât de complex, demn, dar în acelaşi timp şi controversat. Părintele sculpturii moderne, Constantin Brâncuşi, a anticipat un sentiment propriu, afirmând că la umbra marilor copaci, nu creşte nimic. În privinţa lui se pare că a avut dreptate, dar nu şi pe tărâmul spiritual şi filosofic, unde pătrundem, prin analiza unei probleme a celui care a fost numit de către Oracol, cel mai înţelept dintre oameni - Socrate. Acesta a născut în discipoli, setea de dreptate, adevăr şi frumos, care au fost transpuse de către discipolul său Platon, iar mai apoi, la rândul său lui Aristotel, pe hârtie, lăsând lumii o moştenire excepțională.

* PhD Candidate, Faculty of Orthodox Theology, at “1 Decembrie 1918” University, Alba Iulia, Romania. 
„Socrate va face din lumea interioară a sufletului omenesc o problemă cardinală a reflexiunii filosofice, Platon va face din «Idee» realitatea şi esenţa absolută a lumii, iar Aristotel va afirma că «forma pură» este cea mai înaltă realitate. Totuşi, aceştia vor reprezenta concepţia că raţiunea, Logos-ul, este cea mai înaltă realitate faţă de natură, că noţiunea şi forma sunt temeiul lumii"'.

Faţă de alţi filosofi, Socrate este atipic şi prin modul de cercetare $^{2}$. El nu dezvoltă nici un sistem filosofic, el este un „veşnic căutător al adevărului"”3. Urmaşii lui Socrate, atât direcţi, cât şi indirecţi vor avea o influenţă covârşitoare asupra culturii şi teologiei, îndeosebi prin Platon şi Aristotel, formând în acest fel un triptic al filosofiei antice.

După cum amintea un cercetător al filosofie greceşti, această triadă de titani ai filosofiei au avut un rol covârşitor la temelia culturii universale, fiecare având o importanţă deosebită. Astfel că Socrate este asemănat cu sămânța care încolțește, Platon este floarea bogată, iar fructul filosofie antice este Aristotel. Socrate va face

„din determinarea noțională a virtuții problema centrală a filosofiei sale. Ceea ce la preocupat pe acest înțelept antic va fi soluţionarea morală a vieții omenești. Platon şi Aristotel îl vor continua pe Socrate"4

După cum vom vedea, Socrate va fi asemănat unui căutătorul continuu al adevărului, dar nu după mintea omenească, ci spre un ideal concretizat în viaţa de zi cu zi prin înfăptuirea dreptăţii.

\footnotetext{
${ }^{1}$ Nicolae Balca, Istoria filosofiei antice, Bucureşti, Edit. Institutului Biblic şi de Misiune al Bisericii Ortodoxe Române, 1982, p. 101.

${ }^{2}$ Prin Socrate se vor naşte mai multe şcoli de cercetare - aceste fiind socotiţi a fi socratici mici, cu rolul deosebit pe care l-au avut aceştia, pentru mai multe analize a se vedea lucrarea lui Ugo Zilioli (ed.), From the Socratics to the Socratics schools: classical ethics, metaphysics, and epistemology, New York, Routledge Publishing, 2015.

${ }^{3}$ Nicolae Balca, op. cit., p. 101

${ }^{4}$ Ibidem, p. 101-102.
} 


\section{Socrate, un model pentru atenieni ?}

Socrate s-a născut la Atena în 471 î. Hr. Tatăl său era sculptor, iar mama sa moaşă. Acesta va susţine că metoda sa, de a-i învăţa pe oameni este metoda moşitului spiritual, prin care, aduce la viaţă adevărul, din interlocutor. Socrate a primit educaţia specifică perioade, adică noţiunile de bază reprezentau operele aezilor clasici - Homer, Hesiod, şi ale tragicilor. După cum însuşi mărturiseşte, educaţia acestei minţi geniale a dobândit-o printr-o privirea la lumea deosebită a operelor artistice din acestor mare oraş.

Din mărturiile rămase, Socrate este prezentat de urmașii direcți, precum Platon şi Xenofon, ca fiind un om deosebit de modest, rezistent la vicisitudinile vieții și ale naturii, mereu angrenat spre analiza de sine, cufundat în sine. Ia parte cu multă demnitate la campaniile militare desfășurate de atenieni, unde se vădește a fi un soldat destoinic și viteaz, de o mare rezistență fizică și spirituală. Într-o astfel de campanie ajunge printr-un gest eroic să-l salveze pe Alcibiade ${ }^{5}$. Hegel îl descrie ca fiind $o$

„natură tenace, sever faţă de sine şi lipsit de pretenţii, curajos în luptă, rezistând greutăţilor şi încercărilor. Stăpânirea de sine nu are liniştea unei naturi în care nu era nimic de stăpânit, ci dimpotrivă forţa unui spirit mare, care îşi stăpâneşte forţa vulcanică şi un temperament plin de pasiune. Viaţa sa era o pildă de cumpătare şi sobrietate"

După terminarea campaniilor militare se va întoarce în Atena. Aici îşi va petrece restul vieţii, unde va încerca să înnoade dialoguri cu diferiţi concetăţeni în diferite locuri din oraş pentru a le dezvălui propria ignoranţă şi pentru a-i deprinde spre cultivarea virtuţii şi atenţia

\footnotetext{
${ }^{5}$ Platon, Banchetul, trad. după Marsilio Ficino, Timişoara, Edit. de Vest, 1992, p. 82

${ }^{6}$ G.W.F. Hegel, Prelegeri de istoria filosofiei, vol. I, trad. din limba germană de D. D. Roşca, Bucureşti, Edit. Academiei Republicii Populare Române, 1963, p. 371-373.
} 
de sine. El nu a lăsat nimic consemnat în scris. Socrate a hotărât să răspândească virtutea şi înţelepciunea printre convivii săi.

El a trebuit:

„pe de o parte să învingă prejudecăţile educaţiei proprii, neştiinţa altora so lumineze, să surpe sofistica, să reziste răutăţii, invidiei, defăimărilor şi insultelor duşmanilor săi, să poarte cu demnitate sărăcia, să combată puterea ce nu era întemeiată pe drepturi morale şi, ceea ce era şi mai greu, să împrăştie grozăviile superstiţiilor. Iar pe de altă parte să cruţe şi să menajeze cugetele slabe ale concetățenilor săi, să ocolească scandalurile şi să nu ironizeze influenţa bună, pe care o are şi cea mai naivă religie asupra moravurilor celor simpli,"

Este condamnat la moarte în anul 399 î. Hr. Fiind obligat să bea zeamă de cucută.

\section{Cunoaşterea de sine la Socrate}

Scopul vieţii lui Socrate a fost de a-i scoate pe oameni din ignoranţă şi de a-i aduce la exerciţiul virtuţii, şi al grijii de sine. Prin această persoană, ni se întăreşte convingerea, că scopul ultim al filosofiei este întemeierea omului şi a întregii sale existenţe pe temelia adevărului ${ }^{8}$. Pentru Socrate nu era important cu cine vorbeşte, ci cum abordează problema pentru trezirea conştiinţei interlocutorului.

Scoaterea dintr-o tipologie şi superficialitate a gândirii umane, a fost pentru marele filosof un exerciţiu pentru dobândirea cunoaşterii virtuţii, însă prioritară era cunoaşterea de sine: ,am încercat să conving pe fiecare dintre voi să se îngrijească mai puţin de ceea ce are şi mai mult de ceea ce este, astfel încât să devină cât mai virtuos şi mai raţional cu putinţă" " Într-un mod deosebit, este descris de către Platon în Banchetul, prin impactul provocat în urma dialogului cu Socrate:

\footnotetext{
${ }^{7}$ Moses Mendelsohn, Leben und Charakter des Sokrates, Neue Ausgabe, Berlin, 1818, p. 7-8 apud Nicolae Balca, op. cit., p. 105.

${ }^{8}$ G.W.F. Hegel, op.cit., p. 376.

${ }^{9}$ Platon, Apologia lui Socrate 32 d., în „Opere I”, ediţie îngrijită de Petru Creţia şi Constantin Noica, Bucureşti, Edit. Ştiinţifică şi Enciclopedică, 1976, p. 33.
} 
„Adesea mă lăsa într-o asemenea dispoziţie sufletească, încât pur şi simplu simţeam că nu mai pot să trăiesc la fel ca până atunci ... Mă face să admit că, în timp ce îmi ocup vremea cu politica, nu mă îngrijesc de mine însumi" $"$.

Cunoaşterea de sine încorporează mai multe sensuri: primul acela al conştientizării neştiinţei sau a lipsei de înţelepciune; nici un efort spiritual nu poate avea efectul scontat dacă nu există o raportare constantă a cunoaşterii de sine; iar celălalt este acela că prin cunoaşterea de sine se dezvoltă atenţia asupra conştiinţei, vizând perfecţionarea stării morale a practicantului. Socrate a încercat prin toate aceste mijloace care fac posibil exerciţiul cunoaşterii de sine să le folosească în propria viaţă. Cunoaşterea de sine este capabilă să elibereze de o posibilă iluzie aptitudinile individuale, însă celui care i se dedică într-un mod îngust, cunoaşterea de sine nu poate oferi nici o aptitudine $^{11}$. Pe lângă sensul amintit mai sus, de asemenea cunoaşterea de sine nu se reduce doar la înţelesul ei de maximă, adică întoarcerea şi analiza de sine, pe care o are în mod deosebit, ci şi la „cunoaşterea spiritului""12, care este grea, dar în acelaşi timp ea este cea mai înaltă formă de cunoaştere.

Misiunea lui Socrate, după cum se aminteşte şi Apărarea ${ }^{13}$, primită de la zeul Apollo, este de a-i face pe oameni conştienţi de neştiinţa lor. Pentru a-şi duce la bun sfârşit misiunea, în întâlnirile avute cu diferiţi oameni şi filosofi, Socrate i-a asupra sa atitudinea omului neştiutor, a naivului care mereu întreabă. Scopul întrebărilor este de a-i face pe oameni conştienţi de necunoaşterea lor. În toată necunoaşterea sa, Socrate nu doar că era lucid de ceea ce făcea dar şi ştia scopul întrebărilor şi a căutărilor sale. Prin neştiinţa sa încearcă să

\footnotetext{
${ }^{10}$ Idem, Banchetul, p. 75-76.

${ }^{11}$ Jean Brun, Socrate, trad. de Walter Fotescu, Bucureşti, Edit. Humanitas, 1996, p. 72 .

${ }^{12}$ Ibidem, p. 65.

${ }^{13}$ Platon, Apărarea lui Socrate, 20a-23a., în op. cit., p. 18-21.
} 
deschidă ochii interlocutorului, care vede şi analizează superficial. Necunoaşterea la Socrate,

„se adresa celor care nu posede decât o cunoaştere convenţională, cei care nu acţionează decât sub influenţa prejudecăţilor lipsite de fundament raţional, în scopul de a le dovedi că pretinsa lor ştiinţă nu se bazează pe nimic. Dar el îi alege mai ales pe cei convinşi - prin cultura lor - că posedă ştiinţa însăşi”"14.

Modul de abordare a lui Socrate, provoca întrebări, tocmai datorită stereotipiilor societăţii. Socrate vroia să-1 readucă la starea de a descoperi în interlocutor, răspunsurile la întrebări. Răspunsul se află în interlocutor, iar căutarea adevărului este exerciţiul gândirii la care îi supune Socrate pe interlocutori. Responsabilitatea lui Socrate, după cum însuși mărturisește în fața comisiei de judecată a fost de ai întoarce pe oameni la grija de sine:

„am lăsat deoparte cele râvnite de mulţime, trebuirile băneşti şi rostul casei, însărcinarea de strateg, succesele oratorice în Adunare şi tot felul de alte magistraturi, uneltiri şi rivalităţi care sunt în cetate, socotindu-mă prea cinstit ca să pot fi la adăpost, dacă mă apuc de astfel de lucruri, şi nu m-am dus acolo unde nu puteam fi de folos nici vouă, nici mie însumi, ci, socotind că, dacă mă duc la fiecare în parte, îi fac cel mai mare bine, după cum spun, m-am îndreptat spre această îndeletnicire, apucându-mă să-1 conving pe fiecare dintre voi să nu se îndeletnicească de lucrurile sale înainte de a se îngriji de sine, ca să devină cât mai bun şi cât mai înţelept"15.

Dialogul socratic este un examen de conştiinţă, prin aceea că:

„A te cunoaşte pe tine însuşi este fie a te cunoaşte ca nefiind înţelept (adică nu în calitatea de sophos, ci de philo-sophos, tinzând spre înţelepciune), fie a-şi cunoaşte fiinţa ta în esenţa ei (adică a fi capabil să discerni ceea ce suntem cu adevărat, de ceea ce nu suntem realmente noi

${ }^{14}$ Pierre Hadot, Ce este filosofia antică, trad. de George Bondor şi Claudiu Tipuriţă, Iaşi, Edit. Polirom, 1997, p. 55.

15 Platon, Apărarea lui Socrate, 36 c., în op. cit., p. 30. 


\section{$15^{\text {th }}$ International Symposium on Science, Theology and Arts}

înşine), fie a cunoaşte realitatea stării morale în care te găseşti (adică a-şi examina conştiinţa)" ${ }^{\prime 16}$.

În apărarea lui Socrate, se aminteşte că un prieten de-al filosofului, anume Cherephon, a întrebat oracolul de la Delphi, dacă există un om mai înţelept decât Socrate, iar aceasta a răspuns că nimeni nu este mai înțelept ca Socrate. Platon se întreabă, de ce oracolul a spus acest lucru, pentru că Socrate recunoaşte că nu ştie nimic, pe când toţi oamenii, au impresia că cunosc totul, de unde concluzionează Platon, că Socrate este cel mai înţelept, tocmai pentru că este conştient de neştiinţa sa. Oracolul a vrut să spună că Socrate este cel mai înţelept, pentru că faţă de alţi oameni care au impresia că cunosc şi ştiu totul, numai Socrate este cel „care şi-a dat seama că într-adevăr, cât priveşte înţelepciunea, nu e bun de nimic"17. Iar din această prezentare, Platon face o imagine deosebită a lui Socrate, a filosofului care nu ştie nimic, dar care este conştient de neștiinţa sa.

În faţa oamenilor, el se prezintă ca într-o răsturnare a valorilor, pe de o parte imaginea sa, care este vecină cu grotescul, iar pe de altă parte, valoarea interioară a sufletului pe care o promova. În perioada socratică, încă mai exista concepţia asupra armoniei dintre frumuseţea exterioară cu cea interioară. Ori dacă el era, după cum se aminteşte, un chip asemenea cu cel al satirilor, de urâţenia sa chiar şi el se amuza ${ }^{18}$. În acest fel raţionamentul oamenilor era că trebuie să fie o persoană respingătoare şi spirituală. Ori mărturiile din scrierile platoniciene, amintesc de o forţă interioară, o fascinaţie, pe care o producea prin discursuri, dar mai ales prin modul său de a fi. Grija lui Socrate era pentru promovarea şi susţinerea valorilor perene, după cum aminteşte în discursul pentru apărarea sa:

\footnotetext{
${ }^{16}$ Asupra istoricului acestei teme a se vedea P. Courcelle, Connais-toi toi-même. De Socrate à saint Bernard, t. I-III, Paris, 1974-1975, apud. Pierre Hadot, Exerciţii spirituale şi filosofie antică, trad. din limba franceză de Constantin Jinga, postfaţă de Agapie Corbu, Arad, Edit. Sfântul Nectarie, 2015, p. 39.

${ }^{17}$ Platon, Apărarea lui Socrate, 23 b., în op. cit., p. 22.

${ }^{18}$ Anthony Gottlieb, Socrates, London, Orion Publishing Grup Ltd., 1998, p. 11.
} 
„Pentru un om e chiar cel mai mare bine să discute în fiecare zi despre virtute şi despre celelalte lucruri cu privire la care m-aţi auzit vorbind şi supunându-mă pe mine şi pe alţii cercetării, în timp ce viaţa lipsită de această cercetare nu e trai de om, dacă vă spun toate acestea, mă veţi crede cu atât mai puţin"19.

\section{Cunoaşterea de sine şi grija de aproapele}

La Socrate, există o unitate între dialogul cu aproapele şi dialogul cu sine. Dialogul cu sine, dar şi cu aproapele este prezentat ca fiind adeseori sub forma unui solilocviu. Această formă este importantă atât în dialogul cu aproapele cât şi cu sinele, tocmai pentru că numai în acest fel se poate întemeia un dialog rodnic. După cum amintea şi Pierre Hadot, asupra acestei probleme:

„numai acela este capabil de o întâlnire genuină cu celălalt, este capabil şi de o întâlnire autentică cu sine, conversa fiind la fel de adevărată. Dialogul veritabil fiind doar atunci când este prezent atât aproapele dar şi când eşti prezent tu" ${ }^{20}$.

În acest fel trebuie să vedem că scopul dialogului, este atât pentru Socrate cât şi pentru interlocutor, nu este de a transmite informaţii, ci de a provoca o atitudine - o anumită forma mentis - prin care să faciliteze o atenţie asupra grijii de sine, asupra atenţiei faţă de gândurile şi miş̧cările lăuntrice.

Această metodă pe care o foloseşte Socrate, poate avea o dublă semnificaţie. Prima este aceea că acest mod de abordare presupune nu doar cunoaşterea, ci şi dobândirea adevărului. Iar cea de-a doua este că cele două cunoaşteri trebuiesc dobândite personal. Cunoaşterea şi adevărul, prin întrebările pe care le adresează Socrate, sunt de aşa manieră încât descoperă în interlocutor faptul că are o înţelegere superficială şi relativă. De asemenea dialogul socratic, duce la aporie, la imposibilitatea uneori de a firma o cunoaştere. Astfel, cunoaşterea de la o informaţie - cunoştinţă oarecare, trece la cunoaşterea de sine, şi va

${ }^{19}$ Platon, Apărarea lui Socrate, 38a., în op. cit., p. 39.

${ }^{20}$ Pierre Hadot, op. cit., p. 38-42. 
începe prin a-şi pune întrebări asupra propriei persoane. Dar după cum observă chiar un personaj angrenat în discuţie cu Socrate, adevărata întreba nu este despre lucrul care se vorbeşte, ci despre persoana care vorbeşte. În dialogul Lahes, se aminteşte de acest lucru:

„Nu ştii, mi se pare, că acela care, prin părerile şi, parcă, prin neamul său, se află aproape de Socrate şi stă adesea cu el de vorbă este nevoit - chiar dacă mai înainte începe să discute despre altceva - să nu se oprească până nu ajunge, purtat de către şirul gândirii acestuia, să dea socoteală despre sine însuşi, cum trăieşte acum şi care a fost existenţa sa trecută; iar atunci când a ajuns aici, Socrate nu-l va mai lăsa până nu va fi cercetat bine şi frumos absolut totul... Mă bucur să-i stau acestui om în preajmă şi nu cred că este nici un rău dacă ne aducem aminte ceea ce fie că n-am făcut, fie că nu facem cum se cuvine; în plus, prin firea lucrurilor, acela care nu va fugi de aceste adevăruri va fi mai prevăzător în restul vieţii sale" ${ }^{21}$.

Socrate prin întrebările sale este asemenea unui „„ăun”22 care îl pune pe interlocutor să se examineze şi să se înţeleagă pe sine însuşi, dar mai ales să se îngrijească de el însuşi şi de sufletul său.

„O, preabunule, tu care eşti atenian, din cetatea cea mai mare şi mai vestită în înţelepciune şi putere, nu ţi-e oare ruşine că de bani te îngrijeşti, ca să ai cât mai mulţi, şi cât mai multă glorie şi cinstire, iar de cuget, şi de adevăr, şi de suflet ca să fie cât mai frumos, nu te îngrijeşti şi nu-ţi pasă ?"23.

Socrate prin susţinerea neştiinţei şi prin întrebările adresate vrea să aducă în discuţie valorile care guvernează viaţa.

Socrate vrea prin această metodă, să arate sciziunea care se află în interiorul interlocutorului, dintre propria viaţă şi valorile care ne conduc viaţa. Dar şi când ajunge la acest lucru, scopul lui Socrate nu este doar de al face pe cel de apropare să-şi de-a seama că nici el nu ştie

\footnotetext{
${ }^{21}$ Platon, Lahes, 187e., în op. cit., p. 250.

${ }^{22}$ Idem, Apărarea lui Socrate, 30e., în op. cit., p. 31.

${ }^{23}$ Ibidem.
} 
nimic şi este superficial, ci de a fi într-o anumită manieră, după cum însuşi mărturiseşte:

„Am lăsat deoparte cele râvnite de mulţime, treburile băneşti şi administrarea bunurilor, însărcinarea de strateg, succesele oratorice în Adunare şi tot felul de alte magistraturi, uneltiri şi rivalităţi câte sunt în cetate $[\ldots]$ ci, socotind că dacă mă duc la fiecare în parte îi fac cel mai mare bine, după cum spun, m-am îndreptat spre această îndeletnicire, apucându-mă să conving pe fiecare dintre voi să nu se îngrijească de lucrurile sale, înainte de a se îngriji de ceea ce este el, ca să devină mai bun şi mai înţelept" ${ }^{\prime 24}$.

Putem vedea din această afirmaţie, o provocare pentru Socrate, să caute în fiecare zi oameni noi, probleme şi provocări noi în misiunea care a primit-o de la zeu, dar mai ales un mod prin care el trebuie să fie mereu altfel, de a se face înţeles, şi de a se schimba mereu prin asumarea unei cunoaşteri relative. Modul de viaţă al lui Socrate, nu doar că este filosofic, ci mereu învaţă să moară punându-şi propria persoană în faţa limitelor şi neştiinţei, mereu să înveţe dar niciodată să înveţe pe alţii. Filosofia spre care îndeamnă Socate, este de a ne analiza pe noi înşine, cum am spune astăzi, cât mai obiectiv, cu un ochi critic asupra noastră.

Socrate îi face pe oameni să descopere în neştiinţa lor, potenţialul lor interior, faptul că virtutea se află în ei doar că au fost mult prea formali pentru a se analiza şi de a se supune unor critici riguroase. În acest fel trebuie înţeleasă şi afirmaţia socratică, nimeni nu este rău în mod voit, tocmai pentru că nu cunosc, nu pot înfăptui binele $^{25}$. În acest fel Socrate spune că

„dacă omul săvârşeşte răul moral, o face deoarece crede că astfel descoperă binele, şi dacă este virtuos, este pentru că ştie cu întreg sufletul şi cu toată fiinţa sa unde este adevăratul bine. Astfel rolul

\footnotetext{
${ }^{24}$ Ibidem, p. 37.

${ }^{25}$ Virtutea este cunoaştere, după cum se poate concluziona în dialogul Protagoras, după cum aminteşte şi Andrei Cornea, Când Socrate nu are dreptate, Bucureşti, Edit. Humanitas, 2005, p. 110-140.
} 


\section{$15^{\text {th }}$ International Symposium on Science, Theology and Arts}

filosofului va consta deci în a permite interlocutorului să 'realizeze', în sensul cel mai tare al cuvântului, care este adevăratul bine şi care este adevărata valoare. La temelia cunoaşterii socratice se află iubirea binelui" ${ }^{26}$.

Din valoarea absolută care se vădeşte asupra intenţiei morale, chiar şi moartea, în fapt, nu reprezintă un rău, deoarece ,pentru un om bun, nu există nimic rău nici în viaţă nici în moarte"27 - este de fapt concepţia stoică de mai târziu. Pentru Socrate nu există decât păcatul moral, pentru că ţine de propria persoană, pe când boala, moartea, sărăcia, sunt un dat iar ele nu sunt rele.

Deşi nu dă o explicaţie pentru faptul că examinează propria conştiinţă dar şi a celor din jur, se limitează doar a spune că pe lângă misiunea încredinţată de la zeu, el poate mobiliza spre a da un sens vieţii. „O viaţă care nu se supune pe sine cercetării nu merită să fie trăită",28. Această afirmaţie, încorporează esenţa filosofiei sale şi a modului de a trăi ${ }^{29}$. El cheamă şi se poate supune analizei vieţii - a judecării ei în orice moment. Cunoaşterea adevărată nu va putea fi dobândită nicicând, însă prin puritatea intenţiei morale, omul se transformă mereu şi mereu şi acest lucru este asemenea unui urcuş care nu are capăt, şi în care mereu înaintăm.

\section{Grija pentru cetate şi simţământul dreptăţii}

O idee importantă - supunerea faţă de legile cetăţii, nu era doar o datorie, ci pentru acestea, omul trebuie să se şi sacrifice la nevoie. La Socrate chiar şi îndemnul lui Criton de a scăpa de pedeapsă prin fuga

${ }^{26}$ A. J. Voelke, L'idée de volonté dans le stoïcisme, Paris, 1973, p. 194 apud Pierre Hadot, Ce este filosofia antică, p. 63, asupra socratismului trebuie să mai menţionăm că: „dialectica socratică uneşte indisolubil cunoaşterea binelui şi alegerea binelui".

${ }^{27}$ Platon, Apărarea lui Socrate, 41d., în op. cit., p. 43.

${ }^{28}$ Ibidem p. 39.

${ }^{29}$ Sara Ahbel-Rappe, and Rachana Kamtekar, A companion to Socrates, Oxford, Blackwell Publishing, 2006, p. 228. 
din Atena, îi răspunde că printr-o astfel de salvare egoistă ar face o nedreptate faţă de Atena.

„Socrate are o manieră de a se supune care este o modalitate de a rezista" 30 , „se supune legilor pentru a dovedi, chiar în interiorul cetăţii, adevărul atitudinii sale filosofice şi valoarea absolută a intenţiei morale" ${ }^{, 31}$.

Socrate, împlinea misiunea primită de la zeu, atât ca o datorie pe care a simţit-o cu stringenţă dar în acelaşi timp, misiunea era şi de a se apropia de oameni, a descoperi şi greutăţile oamenilor, şi de ai ridica de la problemele cotidiene la lucrarea virtuţilor.

„Socrate este în acelaşi timp în afara lumii şi în lume, depăşind oamenii şi lucrurile prin exigenţa sa morală şi angajamentul pe care îl implică, amestecat cu oameni şi lucruri, deoarece nu poate exista filosofie adevărată decât în cotidian. Şi, în toată Antichitatea, Socrate va rămâne astfel modelul filosofului ideal, a cărui operă filosofică nu constă decât în viaţa sa şi în moartea sa" ${ }^{\prime 2}$.

Din mărturiile vieţii, vedem că Socrate, era o persoană care adeseori se afunda în gândurile sale. Din această cauză rămânea nemişcat multă vreme. Dar acest lucru şi felul de a fi a lui Socrate nu 1a împiedicat să nu aibă grijă şi de aproapele. Din mărturiile păstrate de Platon şi Xenofon, se descoperă în persoana lui Socrate, un om deosebit de preocupat asupra problemelor aproapelui, şi asupra binelui mers al cetăţii. Socrate intra în contact cu diferiţi oameni, atât pe străzile Atenei cât şi cu diferite grupuri, de oameni din oraş. La oamenii cu care intră în contact, Socrate se străduieşte să le trezească conştiinţa morală, şi îndemnul spre virtute, dar acest lucru nu se poate decât numai pornind de la propria neştiinţă şi de la realitate propriei necunoaşteri. Însă pentru ca, aurul să se vădească cu adevărat, a fost

${ }^{30}$ Merleau M. Ponty, Éloge de la philosophie et autres essais, Paris, 1965, p. 38 apud. Pierre Hadot, Ce este filosofia antică, p. 66.

${ }^{31}$ Pierre Hadot, op. cit., p. 66.

${ }^{32}$ Ibidem, p. 66-67. 


\section{$15^{\text {th }}$ International Symposium on Science, Theology and Arts}

nevoie să susţină fără ocolişuri şi prin propriul exemplu, acest lucru, prin acceptare şi descoperirea propriei morţi, că adevărata viaţă este după moarte, prin sentimentul dreptăţii spre care năzuieşte sufletul.

În „Apologia lui Socrate”, Platon ni-l prezintă pe maestrul său în faţa judecătorilor, cu o atitudine de om care cere să i se facă dreptate, o dreptate care ar trebuie să nu aibă de-a face cu nimic din interesele lumii acesteia. Celor care votează pentru condamnarea lui, le aminteşte că vor da răspuns de felul cum vor decide şi în faţa zeilor ${ }^{33}$, iar despre cei care ajung pe lumea cealaltă, spune că dacă vor fi găsiţi drepţi, vor fi alături de celelalte suflete drepte.

Un element important, care ţine de structura interioară a eticii lui Socrate şi pe care Platon 1-a preluat, este dreptatea. Socrate face şi o aluzie la ideea că dacă ei ca şi judecători nu pot face dreptate, moartea lui va fi o apăsare a conştiinţei pentru ei, datorită ticăloşiei de a nu fi judecat drept un cetăţean nevinovat. Chiar dacă este condamnat la moarte cu majoritate de voturi, şi pare înspăimântător acest lucru, totuşi, pentru Socrate ea este ,nici cât negru sub unghie"34. Iar această atitudine nu o exprimă doar cu cuvântul, ci şi cu fapta dacă va trebui. Filosoful mărturiseşte că nu a făcut nici o faptă nedreaptă şi că de acest lucru este încredinţat de glasul zeului pe care îl aude în interiorul său, şi de care a ascultat mereu. Frica pe care a avut-o mereu Socate nu a fost moartea, ci grija de a nu face nelegiuiri sau nedreptate ${ }^{35}$. Putem înţelege din acest mic fragment că filosofia lui Socrate era una întru totul practică.

Împotriva condamnării, că filosoful i-ar fi influenţat negativ pe tineri, Socrate se apără astfel:

„,nu fac nimic altceva decât să colind orașul încercând mereu să vă conving, şi pe tineri şi pe bătrâni, să nu vă îngrijiţ̧i de trup şi de bani nici mai mult, nici deopotrivă ca de suflet, spre a-1 face să fie cât mai bun, spunându-vă că nu virtutea se naşte din avere, ci din virtute vin şi averea

\footnotetext{
33 Pentru mai multe detalii despre Apărarea lui Socrate, a se vedea ultima parte a operei, de la $38 \mathrm{C}$.

${ }^{34}$ Platon, Apologia lui Socrate 32 d., în op. cit., p. 33.

35 Ibidem.
} 
şi toate celelalte bunuri, pentru fiecare om în parte, ca şi pentru cetate. Dacă spunând acestea îi stric pe tineri, atunci aceste lucruri ar putea fi vătămătoare; dar dacă spune cineva că eu vorbesc într-alt fel, n-are dreptate" 36 .

Într-o analiză convingătoare conchide, Georges Bastide că acel om care trăieşte doar pentru bunuri materiale care sunt şi exterioare omului, moartea îi apare ca o nenorocire, pentru înţeleptul care trăieşte în duh, moartea i se prezint asemenea unui lucru firesc, natural. Însă pentru cel care moare, drept fiind şi pe nedrept fiind condamnat, fiind o victimă a nedreptăţii omeneşti, pentru unul ca acesta moartea înseamnă înfăptuire.

\begin{abstract}
„Valorile spirituale se situează în afara timpului şi a spaţiului, ele nu sunt tăgăduite în acest cadru şi orice om care face chiar şi cea mai mică nedreptate pe care o consimte îşi dă seama că-l sacrifică pe cel Drept în afara spaţiului şi a timpului, şi astfel este răspunzător de moartea lui Socrate. Iar pe lângă aceasta Socrate, va fi în agonie până la sfârşitul lumii şi de aceea omenirea nu are voie să doarmă în acest timp"37.
\end{abstract}

Ca un adevărat maestru spiritual, Socrate se apără prezentânduşi roadele, adică ceea ce a făcut el în realitate, învăţându-i atât pe tineri, cât şi pe cei mai în vârstă să aibă grijă în primul rând de suflet. Iar dacă judecătorii socotesc că sunt fapte condamnabile, atunci conducerea şi organizarea polis-ului ar fi problema, nu imboldul la virtute.

O atitudine care vădeşte modul nobil de a fi a lui Socrate, după ce a fost condamnat este că nu are nici o reacţie de împotrivire violentă faţă de condamnarea primită, doar atât le spune celor care 1-au judecat că el se consideră drept şi nu a făcut niciodată nedreptate cuiva. „Dacă cineva i-a făcut rău, acest lucru nu are nici o justificare morală pentru a-i face la rându-i acelaşi rău, sau altul"38. După cum aminteşte

\footnotetext{
${ }^{36}$ Ibidem, 30 a/b., p. 30

${ }^{37}$ Georges Bastide, Le mommént historique de Socrate, Paris, 1939, p. 307-308.

${ }^{38}$ Gregory Vlastos, Socrate - ironie şi filosofie morală, trad. de Mara Van Schaik Rădulescu, Bucureşti, Edit. Humanitas, 2002, p. 148.
} 
profesorul Gregory Vlastos, Socrate, este primul filosof grec care surprinde într-un mod simplu dar fundamental.

„Nimeni nu ştie ce este moartea şi nici dacă nu e cumva cel mai mare bine pentru un om, dar toți se tem de ea ca şi cum ar fí siguri că e cel mai mare rău. Iar în acest fel de a gândi cum să nu fie tocmai prostia aceea vrednică de dispreţ - de a crede că ştii ceea ce nu știi ?"39.

Deşi susţine că nu ştie nimic despre moarte, totuşi susţine cunoaşterea altor lucruri, care sunt mai importante:

„dar a face nedreptăţi şi a nu te supune celui mai bun, fie el om sau zeu, ştiu că acestea sunt fapte rele şi ruşinoase. Aşadar, de nişte lucruri despre care nu ştiu dacă nu cumva sunt bune nu mă voi teme şi nu voi fugi de ele mai degrabă decât de aceste lucruri despre care ştiu sigur că sunt rele" 40 .

Prin cele afirmate mai sus Socrate a vrut să pună accentul pe valoarea sufletului. Dacă asupra morţii, nu ştie nimic, tocmai pentru că „experienţa propriei morţi îi scapă din definiţie”, în schimb recunoaşte că acţiunile morale care depind de el, au o valoare net superioară tocmai pentru că depind de alegerea sa.

Prin moartea lui Socrate, s-a pus temelia concepţiei sale care este fundamentată pe doi mari stâlpi: primul este acela al

„,năzuinței după lumina adevărului constituie, partea nobilă şi eternă a sufletului nostru şi al doilea că nu există un alt mod de a mărturisi adevărul, decât a fi martor al adevărului. Prin viaţa şi existenţa proprie, el, care i-a învăţat pe oameni cum să trăiască, pentru a merita numele de oameni, a ştiut să-i înveţe şi cum trebuie să moară, pentru a se împărtăşi cu nardul veşniciei. Felul în care a murit Socrate înseamnă sfârşitul unui înţelept, care a avut presimţirea unui adevăr etern şi anume că nu moartea este ceva rău, ci viaţa lipsită de o semnificaţie superioară şi că această semnificaţie n-o poate înjosi nici o nedreptate, iar moartea pentru ea nu o poate decât înnobila"41.

${ }^{39}$ Platon, Apărarea lui Socrate 29a/b., în op. cit., p. 29.

${ }^{40}$ Ibidem.

${ }^{41}$ Nicolae Balca, op. cit., p. 115. 


\section{Concluzii}

Privind şi analizând filosofia lui Socrate, existenţialistul Kirkegaard $^{42}$, era conştient că nu poate fi întru totul creștin, pentru că numai Hristos a fost creştin cu adevărat, iar mai aproape de zilele noastre, Cuviosul Sofronie Saharov, mărturiseşte că ,a trăi creştineşte este cu neputinţă, creştineşte se poate doar muri ... aceasta este calea îngustă ce duce la viaţă ${ }^{43}$. Modelul pe care încercăm să-1 urmăm, atât din punct de vedere filosofic cât şi religios nu poate fi îndeplinit în totalitate, însă el trebuie să fie năzuinţa noastră continuă.

După cum amintea Plutarh, câteva secole mai târziu, despre felul de a-şi prezenta filosofia Socrate, care pentru

„majoritatea oamenilor îşi închipuie că filosofia constă în a discuta de la înălţimea unei tribune şi a ţine cursuri asupra textelor. Însă ceea ce scapă cu totul acestor oameni este filosofia neîntreruptă care este exercitată zi de zi într-o manieră perfect egală cu sine [...]. Socrate nu pregătea amfiteatre pentru auditoriu, nu se aşeza la o catedră profesorală; nu avea un orar fix de discuţii în care să se plimbe cu discipolii săi. Însă a filosofat râzând uneori de aceştia, bând sau mergând la luptă sau în Agora cu ei şi, în sfârşit, mergând spre temniţă şi bând otravă. A fost primul care a dovedit că, în orice timp şi loc, în tot ce ni se întâmplă şi în tot ce facem, viaţa de zi cu zi oferă posibilitatea de a filosofa ${ }^{44}$.

După cum nu se putea prezenta mai bine, viaţa trăită intens, devine un mod de a fi şi apoi un mod de a zice. La Socrate aceste lucruri se află într-o armonie continuă. Pentru acest lucru este el important, unitatea pe care a dobândit-o practicând filosofia, în cel mai fíresc mod de a fi - omul - antropos - liber, care priveşte spre cer şi îşi cunoaşte

${ }^{42}$ Søren Kierkegaard, L'Instant, 10 în „Oeuvres complètes”, vol XIX, traduction par Paul-Henri Tisseau et Else-Marie Jacquet-Tisseau, Paris, 1982, p. 300-301.

${ }^{43}$ Sofronie Saharov, Viaţa şi învăţătura stareţului Siluan Athonitul, ed. II, trad. de Ioan I. Ică jr., Sibiu, Edit. Deisis, 2004, p. 265.

${ }^{44}$ Plutarh, Si la politique este l'affaire des vieillards, 26, 796d apud Pierre Hadot, Ce este filosofia antică, p. 67. 
vocaţie şi rostul în viaţă. Iar pentru că Socrate şi-a cunoscut rostul în viaţă, şi 1-a aflat şi în moarte.

Modul de a se îngriji de sine dar şi de ceilalţi, schimbă structura interioară, lărgind-o, să nu fie om al oportunităţilor şi cu interese, să fii - politropos, ci persoana - chipul - prosopon al celui Necreat. Astfel omul trebuie să se conducă după legea care este în sine şi să accepte şi legile acestei lumi - pentru a trăi şi a muri după legile acesteia, dar a muri pentru ceva mai presus decât lumea şi viaţa aceasta - iar acest lucru este un ideal, care ni se împărtăşeşte cu cât ne apropiem gândul de divin. Viaţa lui Socrate a fost deosebită, chiar mare, dar mai mare a fost atitudinea morţii sale.

Vocaţia şi destinul lui Socrate, impregnată peste secole în conştiinţa lumii este aceea de a fi trezitorul sufletului uman din somnul în care se cufundă omul prin activitatea cotidiană şi de sub abisul părerilor, pentru a-l face să ajungă la adevăr. Valoarea sufletului este pentru Socrate inestimabilă dar şi salvarea acestuia prin exerciţiul adevărului este marea chemare a filosofului. Platon îl consideră pe maestrul său, trezitor al omenirii înspre lumina adevărului, redându-i în acelaşi timp imaginea eternă şi prototipul filosofului autentic, acela de a face din orice clipă din viaţă o filosofie, un continuu urcuş al sufletului spre lumină, adevăr şi dreptate. Toate acestea nu se pot realiza decât numai dacă omul va dori să se lase modelat de către conştiinţă.

\section{Bibliografie}

- Balca, Nicolae, Istoria filosofiei antice, Bucureşti, Edit. Institutului Biblic şi de Misiune al Bisericii Ortodoxe Române, 1982.

- $\quad$ Bastide, Georges, Le mommént historique de Socrate, Paris, 1939.

- Brun, Jean, Socrate, trad. de Walter Fotescu, Bucureşti, Edit. Humanitas, 1996.

- Cornea, Andrei, Când Socrate nu are dreptate, București, Edit. Humanitas, 2005.

- Gottlieb, Anthony, Socrates, London, Orion Publishing Grup Ltd., 1998. 
- Hadot, Pierre, Exerciţii spirituale şi filosofie antică, trad. Din limba franceză de Constantin Jinga, postfaţă de Agapie Corbu, Arad, Edit. Sfântul Nectarie, 2015.

- Hadot, Pierre, Ce este filosofia antică, traducere de George Bondor şi Claudiu Tipuriţă, Iaşi, Edit. Polirom, 1997.

- Hegel, G. W. F., Prelegeri de istoria filosofiei, vol. I, traducere din limba germană de D. D. Roşca, Bucureşti, Edit. Academiei Republicii Populare Române, 1963.

- Kamtekar, Rachana, and Sara Ahbel-Rappe, A companion to Socrates, Oxford, Blackwell Publishing, 2006.

- Kierkegaard, Søren, L'Instant, 10 în „Oeuvres complètes”, vol. XIX, traduction par Paul-Henri Tisseau et Else-Marie Jacquet-Tisseau, Paris, 1982.

- Platon, Banchetul, trad. după Marsilio Ficino, Timişoara, Edit. de Vest, 1992.

- Platon, Opere I, ediţie îngrijită de Petru Creţia şi Constantin Noica, Bucureşti, Edit. Ştiinţifică şi Enciclopedică, 1976.

- $\quad$ Ponty, M. Merleau, Éloge de la philosophie et autres essais, Paris, 1965.

- Saharov, Sofronie, Viaţa şi învăţătura starețului Siluan Athonitul, ediţia a II-a, trad. de Ioan I. Ică jr., Sibiu, Edit. Deisis, 2004.

- Vlastos, Gregory, Socrate - ironie şi filosofie morală, trad. din limba engleză de Mara Van Schaik Rădulescu, Bucureşti, Edit. Humanitas, 2002.

- Zilioli, Ugo (ed.), From the Socratics to the Socratics schools: classical ethics, metaphysics, and epistemology, New York, Routhledge Publishing, 2015. 